\title{
SOCIAL APPROACH IN TAFSIR AL-QUR'AN PERSPECTIVE OF HASAN HANAFI
}

\author{
Ade Jamarudin \\ Fakultas Ushuluddin UIN Suska Riau \\ Ade.Jamarudin@uin-suska.ac.id
}

\begin{abstract}
Hasan Hanafi states that a thorough revival in religious reforms affects social revolution and Muslims' politics, interpretation methodologies are needed go beyond the textual and historical interpretations, which do not take al-Qur'an in a narrow space and time in Rasulullah period, Hasan Hanafi gave a social approach in interpreting the Qur'an (almanhaj al-ijtima' $i$ Fi at-Tafsir). With this interpretation, according to Hanafi, an exegete who want to find the meaning of al-Qur'an do not only deduce the meaning of the text, but on the contrary, can induce the real meaning into the text. Interpret according to Hasan Hanafi means looking for something, object focus. Interpreting is to find something new among language text. It uses thematic method that is characteristic of interpretation by the scientific paradigm, which expresses the subjectivity emphasis of commitment interests and interpreter objective socially.
\end{abstract}

Keywords: Manhaj al-ijtima 'i, Tafsir al-Qur'an, Hasan Hanafi

\section{Introduction}

Qur'an is not just a text like other texts; it is a text create the rules of life and living, Moreover, from this text, there are millions books present in compilation of doctrine and religious edicts or in interpretation books. The presence of al-Qur'an in various communities civilizations become a central circle of religious discourse that never stopped, likewise, it create big centripetal movement that became the main reference to obtain justification regarding various issues. It performed a centrifugal motion that became the impetus for the meaning development and interpretation. ${ }^{1}$

Qur'an Verses are not sufficient if one is only able to read and sing well, but more than the ability to understand and uncover the contents and to find out the principles it contains. As a

${ }^{1}$ Teks, Jurnal Study al-Qur'an (Bandung: RqiS, 2002), 1. form of realization of an effort to understand the meaning of the text that can be applied in life has given rise to many approaches and methodologies as well as contemporary approaches, one of hermeneutics has inspired contemporary Muslim scholars to read the new discourse, like Arkoun, Hasan Hanafi, Farid Esack and Nasr Hamid Abu Zaid, in doing the interpretation. ${ }^{2}$

The interpretation of the Qur'an with different editorial implies similar definition, which focus on the interpretation activities are to find the information about God's purpose contained in Qur'an and process is merely human abilities. From this centrifugal motion Qur'an interpretation discourse evolved into a religious tradition from generation to generation relatively relate to rules of the language and the meaning

${ }^{2} \mathrm{M}$. Aji Nugroho, Hermeneutika al-Qur'an Hasan Hanafi (dari Teks ke Aksi; Merekomendasikan Tafsir Tematik/ Maudhu'i), 1. 
of vocabulary. In other words, the tradition of alQur'an study appears as an action that leads to the text alone, and interpretation is dependent on form of text, and the subjectivity of the interpreter. $^{3}$

The interpretation of al-Qur'an like this took place in quite a long time till develop of various scientific methods whose inclinations are looking for objectivity, which is intended to reveal meaning objective of al-Qur'an in other words "let the Qur'an speak for themselves" and interpretation undergoing a paradigm. Along with the dynamics of society and socio-cultural transformation, interpretation discourse grows with style and methods vary. Marking the beginning of a new era of this interpretation, Muhammad Abduh performed introduce methods of interpretation with an emphasis Mufassir must see the Qur'an as a book of guidance only, is intended to keep the assumption that Qur'an as a book of law and dogma so as not to be speculation theoretical or scientific citations out of guidance of the Qur'an itself. ${ }^{4}$ From the Abduh pioneering grow tendency objectivity followed by next generation like Amin Al-Khulli, Muhammad Khalafullah, Nasr Hamid and so on, with style and variations of each originator, excluding Hasan Hanafi.

Hasan Hanafi interpretation is very important to be studied, because is there is a method of interpretation initiated by AlFarmawi. Tafsir is not only identified with understanding the text, interpretation should find something new among the subtitle. Interpret is same as a write a new text, revealing the innermost contents of the text language of al-Qur'an.

\section{Biography Life Hasan Hanafi}

Hassan Hanafi is a Professor at the Faculty

\footnotetext{
${ }^{3}$ Abdul Mustaqim \& Sahiron Syamsuddin (ed), Study alQur'an Kontemporer (Yogyakarta: Tiara Wacana, 2002), 97-98.

${ }^{4}$ Ibid., 99.
}

of Philosophy of the University of Cairo. He was born on February 13, 1935 in Cairo, near Fort Salahuddin, the township area of al-Azhar. Although the social environment can be said to be too supportive, scientific tradition flourished there since long. Historically and culturally, the Egypt has indeed been influenced great civilizations since the time of pharaohs, Roman, Byzantine, Arab, Mamluk and Turkey, even up to modern Europe. ${ }^{5}$ This suggests that Egypt, particularly Cairo, is significant importance for the early development of scientific tradition Hasan Hanafi. Besides, he also studied the thinking of Sayyid Quthub about social justice and Islamic.

His education begins in elementary education, graduated in 1948, then Junior High School of "Khalil Agha", Cairo, was completed in 1952. While in Junior High School, Hanafi has been actively participating in the discussions alMuslim Brotherhood, ${ }^{6}$ from these activities Hanafi thinking developing, in addition, he also studied the thoughts of Sayyid Qutb about social Justice and Islamic. After graduating from Junior High School, Hanafi continued his studies at the Department of Philosophy of the University of Cairo, completed in 1956 with the title of baccalaureate, and then continued his studies at

\footnotetext{
5 'Iwad, Dirasat fi al-Hadlarat (Kairo: Dar al-Mustaqbal al-'Arabiy, 1989), 133.

${ }^{6} \mathrm{Al}$-Ikhwan Al-Muslimûn was built in town Ismaili, Egypt on Mach 1928 with founder Hassan al-Banna, along with six other figures, namely Hafiz Abdul Hamid, Ahmad alKhusairi, Fuad Ibrahim, Abdurrahman Hasbullah, and Zaki Ismail Izz al-Maghribi. Al-Muslim Brotherhood is an Islamic organization based on Islamic teachings. He is one of the few pilgrims pilgrims existing on Muslims, who believe that Islam is a deen universal and comprehensive, not just a religion in charge of ritual worship (prayer, fasting, hajj, zakat, etc.) only. Al-purpose Muslim Brotherhood is to realize the formation of the figure of the Muslim individual, household Islami, an Islamic nation, the Islamic government, the state led by Islamic countries, unite split the Muslims and their countries were deprived, then carrying the flag of jihad and da'wah to Allah so that's getting peace with Islamic teachings. Al-Muslim Brotherhood rejects all forms of colonialism and the proWestern monarchy.
} 
the Sorbonne in France, by taking the concentration on the study of pre-modern Western thought and modern. ${ }^{7}$ Hanafi completed master's and doctoral programs in 1966, with a thesis entitled Les methodes d'Exegeses: Essei sur La Science des Fondament de La Conprehension Science Usul Fiqh and dissertation titled L'exegesis de La Phenomenologie, L'etat actuel de la Methode Phenomenologie et son application au Phenomene Religiux. ${ }^{8}$

His academic career began in 1967 when it was appointed as lecturer, then associate professor in 1973, then a professor of philosophy in 1980 at the Department of Philosophy of the University of Cairo. Besides Hanafi also actively giving lectures in several countries, such as France, Belgium, USA, Kuwait, Morocco and Japan. In 1984-1985 he was appointed as a visiting professor at Tokyo University, and an advisor program at United Nations University in Japan in 1985-1987. Besides the academic, Hanafi is also active in the scientific organization and social. He is active as General Secretary of the Union of Egyptian Philosophy Society, member of the Asian-African Writers Association, member of the Afro-Asian Solidarity Movement and became vice president of the Union of Arab Philosophy Society. ${ }^{9}$ his thinking spreads in the Arab and Europe, 1981 initiated as well as the chief editor of the scientific journal publishing alYasar al-Islamai.

Over in France, Hanafi explore various disciplines. He studied methods of thinking, renewal and the history of philosophy of Jean Gitton, learning analysis in Pauk Ricouer awareness, learning field Massignon renewal at the same time act as supervisor of dissertation, as

${ }^{7}$ Hasan Hanafi, ad-Dîn wa at-Tsaurah fi Micr 1952-1981, al-Yamîn wa al-Yasâr fî fikri ad-Dînî Vol. 7 (Kairo: Maktabah Madbuli, 1989), 331-332.

${ }^{8}$ Ahmad Khudori Sholeh, Pemikiran Islam Kontemporer, Hasan Hanafi: Hermeneutika Humanistik (Yogyakarta: Jendela, 2003), 157.

${ }^{9}$ Ibid., 158. well as studying phenomenology of Husserl. Nowadays, Husserl's phenomenology influenced Hanafi thinking in reading religious texts. Edmund Husserl's phenomenology is as a basic of his thinking in L'exegesis de La Phenomenologie, L'etat actuel de la Methode Phenomenologie et son application au Phenomene Religiux, Les methodes d'Exegeses: Essei sur La Science des Fondament de La Conprehension Science Usul Fiqh, and La Phenomenologie d L'exegesis: essai d'une hermeneutique existentielle a parti du nouvea Testanment. ${ }^{10}$

His relation with different methodologies above, lead Hanafi to prepare a project of a comprehensive renewal of Islamic thought (almanâhij al-Islami al-'Amm). Hanafi start this project after return to Egypt and start to assume atTurath wa at-tajdid (tradition and modernization).

Hanafi perform projects at-Turath wa attajdid project based on three inter-related agendas. Firstly, the reconstruction of Islamic tradition to perform a critical interpretation and historical criticism reflects "an appreciation of classical literatures" (mawqifunâ min al-Qadim). Second, reconstruct against Western cultural boundaries through a critical approach that is reflected in "our attitude towards the West" (mawqifunâ terminal-Gharb). Then, an attempt to build a theory of al-Qur'an interpretation which frees from cultural dimension of religion on a global scale, take Islam as the ideological foundation for humanity. The third agenda reflects "our attitude towards reality" (mawqifunâ terminal-waqi). ${ }^{11}$ The results from Hanafi literature, it found there is no work produced by Hanafi. Hanafi just put the premises, the methodology of interpretation and interpretive characteristics that must be resulted from the process of interpretation.

\footnotetext{
${ }^{10}$ Ahmad Khudori Sholeh, 332.

${ }^{11}$ Ilham B. Saenong, Hermeneutika Pembebasan, Metodologi Tafsir al-Qur'an menurut Hassan Hanafi (Jakarta: Teraju, 2002), 71-75.
} 
If the new Islamic Left is basic thoughts that have not provided details of his program of reform, Min al-Aqeedah book ila al-Tsaurah (5 volumes), which he wrote for nearly ten years and published in 1988. This book contains a detailed description of the main points of reform that he decides to and contained in both his earlier work. Therefore, it's not without reason that the book is said to be the most monumental Hanafi work.

\section{Masterpiece of Hasan Hanafi}

Masterpiece of Hanafi can be classified into three periods; the first period took place in the 60s; the second period in the 70s, and the third period from the $80 \mathrm{~s}$ to the $90 \mathrm{~s}$. The analysis on Hanafi thinking developed based on period of works. Each period contain development of thinking Hanafi and political dynamics in Egypt has a major influence on his thinking. In the early 1960s Hanafi thinking was influenced by the ideology-the dominant developed in Egypt, the nationalistic-socialistic populist is also defined as the ideology of Pan Arabism, and by the unfavourable national situation after Egypt's defeat in the war against Israel in 1967. His attempt to reconstruct Islamic thought, when he was in France he conducted research on, methods of al-Qur'an interpretation as an effort to reform ushul, and about phenomenology as a method to understand religion in contemporary reality context. It is attempts to interpret the reality of Muslims in the new framework. This research is as attempt to get a doctorate at the Sorbonne, and he succeeds to write a dissertation on the method of interpretation which received an award as the best scientific work in Egypt in 1961. The beginning period of the 1970s, Hanafi also provide focusing to find the cause of Islam defeat in the war against Israel in 1967. Therefore, his writings has populist characteristic. At the beginning of the 1970s, he wrote many articles in various media, such as Al-Katib, Al-Adab Al-Fikr al-Mu'ashir, and the pulpit of Al-Islam. In 1976, the writings were published as a book with the title Qadhaya Mu'ashirat fi Fikrina al-Mu'ashir.

Then, in 1977, he published Qadhaya back $\mathrm{Mu}$ 'ashirat fi al Fikr al-Gharib. This book discusses the thinking of Western scholars to see how they understand human problems and then hold an update. Meanwhile Dirasat Islamiyya, which was written in 1978 and published in 1981, contains a description and analysis of the renewal of the classical Islamic sciences, such as Ushul fiqh, Ushuluddin sciences, and philosophy. Starting with a historical approach to see progress, Hanafi talked about the reconstruction efforts on these sciences to conform to contemporary reality. The next period, the decades 1980 s to early 1990 s, motivated by the political conditions are relatively more stable than ever before. In this period, alHanafi wrote Turatswa al-Tajdid first published in 1980 . The book is a theoretical foundation that includes the basics of reform idea and steps. Later, he wrote al-Yasar al-lslamiy (Left Islam), a "political manifesto" writing about ideological, as already mentioned briefly before.

Min al-Aqeedah ila al-Tsaurah book (5 volumes), he wrote it for nearly ten years and published in 1988. This book contains a detailed description of the main points of reform that he decides to and contained in his book before. Therefore, there is no reason that the book is said to be the most monumental works of Hanafi. Furthermore, in the years 1985-1987, Hanafi wrote many articles which he presented in various seminars in several countries, like the United States, France, The Netherlands, Middle East, Japan, including Indonesia. A collection of writings then compiled into a book entitled Religion, Ideology, and Development, published in 1993. Several other articles also composed into a book and titled Islam in the Modern World (2 volumes).

Father from three children wrote at least 20 books and dozens of scientific papers. The popular writing in Indonesia, among others, alYasar al-Islami (Islamic Left), Min al-'Aqeedah ila al-Thawrah (From Theology to the 
Revolution), Turath wa Tajdid (Tradition and Renewal), Islam in the Modern World (1995), and others. Hasan Hanafi is not just a revolutionary thinker, but also classical Islamic Intellectual tradition reformist.

\section{Characteristics Hasan Hanafi}

Hasan Hanafi is a reformer and activist movement of the Muslim Brotherhood, thinker who has a commitment to the people, stand up for Islamic society and deep concern over the condition of the people and intellectual heritage, as academic remain to Western scientific methodological. Line in this reason, Hanafi is very eager to try to let reality speak about him. From personality, explored renewal of ideas focused on Ihya al-Turath, dismantle Western supremacy, and lifting the reality of Islamic world.

Ihya al-Turath, intended as an attempt to reconstruct, purify and develop discipline in traditions and treasures of classical Islam. AlQur'an study and interpretation are part of the repertoire that should be revitalized by alternative interpretation methodological and has certain characters where he considered effective. Dismantling the supremacy of Western civilization, Western had ambition to make himself as a progress paradigm for other nations, and then this myth should not be allowed. Lifting the reality of the Islamic world, the reality of the Islamic world according to Hanafi is a phenomenon of imperialism, capitalism, poverty, authoritarianism, oppression and underdevelopment way out is no longer with the textual normative approach, but rather phenomenological approach, which is based on the historical socialist empirical reality become indispensable for leading the change renewal of Islamic society, that's why he gives priority to reality approach rather than textually. It is the primary frame thinking of Hanafi particularly relate to interpretation of al-Qur'an problems. ${ }^{12}$

${ }^{12}$ Ibid., 101-102.

\section{Framework of Hasan Hanafi}

According to Hasan Hanafi, revelation process is a process of communication that has three components: sender, message, and recipient. In Islamic studies, human discourse that often be as basis of human tragedy has been overlooked, while, these components is a major in communication process as a recipient of the message (the object of revelation). According to this thinking impression text is everything, so the reality is always viewed from the sound of the text, the text is considered as create reality, rather than reality became the standard. It's meant, a revelation does not lead to create empirical (reality), but rather the opposite. So without this reference text will be out of meaning.

Hasan Hanafi assumes that the priority interpretation do not explain al-Qur'an, but problem solving in society, because this is empirical problem is as basic of text. In fact, alQur'an states that presence preceded by the problems and questions rose by reality. According to the classical interpretation tend to be longwinded and repetitive so do not pay attention to the needs. ${ }^{13}$ As in his book which has been published by paradigm Occidentalism; our attitude toward Western tradition in its original title Muqadimah Fi Ilm Al Istighrab. In these works, he invites the readers jihad against the West, precisely for the sake of liberation theology. If it saw from the theoretical-philosophical sprectur, thought Hasan Hanafi is revolutionary left. As someone who has a strong sense of reality, Hasan Hanafi has a empirical view or grounded. As a Muslim reformer, he is as bearers of Islam Critical thinking and Islamic civilization. Strategy of human culture is as a conscious effort to solve difficulties, obstacles, contemporary and new issues.

Hasan Hanafi has a concern to real Muslims problems such as injustice, oppression, colonization. The thinking is same as his friend

\footnotetext{
${ }^{13}$ Ibid., 103.
} 
Ali Shariati one Iranian ideologue who is same learn in Sorbonne. Hasan Hanafi in comprehensive cultural strategy is called as tradition and modernization projects. In the project he scheduled three main agenda of our attitude towards tradition, our attitude toward western traditions, and our attitude towards reality. The all of agenda is the dialectic of the ego with him, it is the legacy of the past, and dialectic with others, within a certain time that dialectic with the present. Three of agenda by Hasan Hanafi is as an act which is not just intellectual exercises, but is intended as a real change in the Islamic world.

In the first agenda Hasan Hanafi has published a monumental work under the titled Min al Aqidah ila ats-Tsawrah ats. The book has been translated by Paradigm with the title of Aqeedah Towards the Revolution, after his second Occidentalism; Our attitude towards the Western tradition. In these works Hasan Hanafi has described the importance of revelation about human and history about Classical Islam theology, but often hide or deliberately hidden behind images of God. Islamic theology always says about perfection of God rather than human meaning of the themes in the history. Hasan Hanafi transform theological dogmas into a revolutionary ideology in Islam. While in second agenda makes Occidentalism into a new scientific discipline in Islamic thought. He mentioned the study as a criticism of depictions and the formation of structure western consciousness. A kind of west is deconstruction of the west by using Islam view. The purpose of the agenda is to the end of the invasion western culture toward Muslims by returning them to cultural boundaries. As the culture of the Muslims who have a dependency on western nations, which led to the neglect of a very rich tradition.

The first and second agenda clearly show the originality of his thinking as a cultural strategy for Muslims life. Hasan Hanafi did deconstruction, he also did a reconstruction at the same time presents a critique of Islam reality through liberation theology transformative. As the question of how Hasan Hanafi see interpretation methodologies which contains the text-based with reality.

\section{Manhaj Tafsir al-Qur'an Hasan Hanafi}

Interpret according to Hassan Hanafi more means doing a double movement from text to reality and reality into the text. Therefore, it offers a methodology of interpretation known as alManhaj al-ijtima'i fi At-Tafsir, ${ }^{14}$ it's called as thematic method, ${ }^{15}$ with three basic principles as follows:

1. In al-Qur 'an interpretation does not need to ask origins and nature. Because the interpretation is not associated with the origin but rather related to the content of the text.

2. Al-Quran as the other text, whether sacred or secular. Namely the interpretation of the alQuran is not built on the assumption that a 1Quran is a sacred text with all its privileges.

3. Categorization distinguish between texts with the interpretation, the interpretation did not know right or wrong normative assessment. ${ }^{16}$ As a result, a plurality of interpretations is unavoidable.

As a method, according to the Hanafi interpretation of al-Manhaj Al-ijtima'i has eight rules, with the intention of interpretation become social interpretation and social structures, ${ }^{17}$ namely:

a) socio-political commitment.

An interpreter must be an agent of social change which gives pride as Al-Afghani, Sayyid Qutb, and so forth to their readers.

\footnotetext{
${ }^{14}$ Abdul Mustaqim dan Sahiron Syamsudin, Studi AlQur'an Kontemporer: Wacana Baru Berbagai Metodologi Tafsir (Yogyakarta: Tiara Wacana. 2002), 103-104.

${ }^{15}$ Fariz Pari, dkk., Upaya Integrasi Hermeneutika dalam Kajian Qur'an dan Hadits (Teori dan Aplikasi): Buku 1 Tradisi Islam (Yogyakarta: Lembaga Penelitian Universitas Islam Negeri Sunan Kalijaga, 2012), 165.

${ }^{16}$ Abdul Mustaqim dan Sahiron Syamsudin.

${ }^{17}$ Ibid., 105-106; see Fariz Pari, 176-210.
} 
b) Formulate the goal.

Not possible for someone or Mufassir started the activities without any awareness of what he want to achieve. Readers (qasd alQari) are being first priority rather than the author (qasd al-shari '). This is a development of the first rule, that muffasir must orient his consciousness to the purpose of problem solving, based on the priority requirement service and Muslim welfare is wider.

c) Inventory verses about a desired theme.

d) Classification of language form.

Language is a thread to sent contents of mind or meaning. Such haqiqi and majazi, muhkam and mutasyabih, mujmal and mubayyan, Zahir and mu'awwal, muthlaq and muqayyad, 'amm and Khass, etc.

e) Build a precise meaning with the appropriate target.

f) Analysis of factual situation faced by the interpreter.

It was a step to redress by minimizing the subjectivity of the interpreter. By adhering to the formulation of how the way of thinking that sees a past event related to Muslims now and future.

g) The comparison between ideals with reality through statistical calculations and social sciences, as a measure to minimize the subjectivity of the interpreter with subjectivity position directly between text and reality.

h) Description of action, as the final step of interpretation that transformative process to produce practical formulation.

He refused if the interpretation identified only as a theory to understand the text, according to him interpretation means doing a double movement from text to reality and from reality to the text. He also rejected an assumption about objective meaning can discovery by contemporary commentators, because of the distant intervals between history text with time interpreter.

Hasan Hanafi build hermeneutic rationale in four pillars; from the classical repertoire he chose ushul al-fiqh, while phenomenology, Marxism, in hermeneutics itself, from the western intellectual tradition. This is a new design of interpreter majority and al-Qur'an interpretation methods is still limited by using the philology approach, transmission law or history report, theology, philosophy, mystical studies, justification science discovery, the study of the socio-political, aesthetic approach to the al- Quran. In the classical repertoire he chose usul al-figh is practically he saw a close link on interpreter activities, with the process of law. It is due to formulate the law in order to see the social reality that has a very complex problem in the Muslim world.

Hermeneutic Hasan Hanafi also influenced by Hans George Gadamer's hermeneutics. The relationship between both of this hermeneutic took on the assumption of interpreter can not separate from interpreter subjectively which is called preunderstanding. Activity interpreter always involves a certain view of the object that he interpreted. Therefore, the processes of interpretation are equivalent and find new meanings that interpretation to be creative. It involves phenomenological approach particularly in connection with criticism or trasendensi, by strive interpretation on the basis of the experimental experience of the interpreter. Phenomenology which he meant as an apodictic method science allowed the doubts and absolute. With this view he describes the knowledge gained should not be derived from doubt but must be built on an awareness of things reality as they are. The only valid knowledge is through direct intuition without any intermediaries. This makes the awareness toward a "consciousness", the phenomenology is said to consciousness "intensionalisme".

In numerous articles, papers and specifically is in introduction Tradition and Modernization book (at-Turath wa atTajdid) Hanafi states that mega projects instead of Tradition and Modernization is a reconstruction 
effort of civilization to show the sources in revelation, or reinterpretation revelation itself, based on the reality of contemporary and classical traditions. The last goal is the revelation transform into a comprehensive humanitarian discipline. ${ }^{18}$ For that purposes, Hanafi plans a hermeneutics includes various theories of interpretation, either on the text and the reality.

Hanafi used hermeneutics as an alternative method of text interpretation in a critique of the classical interpretation methods. Hanafi also expands the scope of hermeneutics, than just interpretation science or theory of knowledge, be a science that describes acceptance of revelation from the word level to the world level. Hermeneutics is the study revelation process from the letters to reality, from logos to praxis, and also transformation of the revelation from God to human life. ${ }^{19}$

Hermeneutic etymologically derived from the Greek hermeneue in English hermeneutics (to interpret) means interpret, explain, interpret or translate. ${ }^{20}$ The word hermeneutic was originally referred to the name of the ancient Greek deity is Hermes, which is in charge of delivering the message deity to humans. In another version narrated that Hermes was the messenger of Jupiter to humans. Hermes described as one who has winged and is known as Mercury. The main task of Hermes is to convey messages from Olympus mount into a language that can be understood by humans.

Hermes is very important because when there is misunderstanding about the message from deity will be fatal to humans. Hermes should be able to interpret or translate a message into the language used by listeners. Since then, Hermes became a symbol of an ambassador is burdened

${ }^{18}$ Hasan Hanafi, At-Turâtswa at-Tajdîd: Mauqifunâ min al-Turâts al-Qadîm (Kairo: Al-Markaz Al-'Arabî, 1980), 213.

${ }^{19}$ Ahmad Khudori Sholeh, 160-161.

${ }^{20}$ Imam Chanafie Al Jauhari, Membangun Peradaban Tuhan di Pentas Global (Yogyakarta: Ittaqa Press, 1999), 21. with a certain mission. Obviously the success of the mission depends on how the message was delivered.

According to Seyyed Hossein Nasr, Hermes is none other than the Prophet Idris in philosophy is called fathers of philosophers. Meanwhile, according to a history that is circulated among schools, task for Prophet Idris was a weaver. If the profession weaver associated with the myth of Hermes then there is a positive correlation. The verb spin equivalent in Latin is tegere, while the product is called textus or tex which is the central issue of the study of hermeneutics.

Looking at the various flaws and weaknesses in the classical commentators, Hanafi give a new theory of interpretation in interpreting the Qur'an which he formulated through a social approach, Hanafi calls this theory "social hermeneutics" (al-manhaj al-ijtima'i Fi at-Tafsir), or more precisely the method of thematic interpretation (at-Tafsir al-mauû' $\hat{\imath})$. With hermeneutics al-Quran, according to Hanafi, an exegete who want to find the meaning of AlQur'an is not only deduce the meaning of text, but on the contrary, can also induce a real meaning into the text. Not only explanation, but also to understand. Not only know but realized. A mufassir not only receive, but giving meaning. He received meaning and put it in a rational and concrete. Thematic interpretation tries to find the true identity in revelation, consciousness and nature. $^{21}$

According to Hanafi interpreting is looking for something, the focus of the object. Interpreting is to find something new among the language of the text. Interpret according to Hanafi, same as write a new text, revealing the innermost contents of the text relate to the deepest consciousness. ${ }^{22}$

\footnotetext{
${ }^{21}$ Hasan Hanafi dalam Ilham B. Saenong, Hermeneutika Pembebasan, Metodologi Tafsir al-Qur'an Menurut Hassan Hanafi (Jakarta: Teraju, 2002), 146.

${ }^{22}$ Ibid., 147.
} 
Associated with social Hermeneutical methodology, Hanafi put the premises and philosophical to find the meaning from alQur'an. Premises are: First, the revelation placed in the "parentheses" (epoche) ${ }^{23}$ not affirmed nor denied. Interpreters do not need to ask the validity and authenticity of Qur'an which debated by the Orientalists, even some contemporary Muslim scholars such as Nasr Hamid Abu Zayd and Mohammed Arkoun, ${ }^{24}$ whether he is from God or from the view of Muhammad. Interpretation starts from the text as it is without ask the authenticity first. According to Hanafi, the question about the origin of the text in interpretation is not relevant anymore, because the text is the text, there is no problem whether it is divine or human, sacred or profane, secular. The question about the origin of the text is the text of the problem occurrence, whereas the interpretation relate to the content of the text. ${ }^{25}$ Second, A1-Qur'an is accepted as appropriate other texts, such as literary, philosophical texts, historical documents and so on. Al-Quran does not have a special status methodologically; all the text is interpreted by the same rules. Whether it is sacred or profane include the Qur'an. Al-Qur'an according to Hanafi, is a transfiguration of human language, as well as the hadith of the Prophet. ${ }^{26}$

\footnotetext{
${ }^{23}$ Kata epoche berasal dari bahas Yunani, yang berarti: "menunda putusan" atau "mengosongkan diri dari keyakinan tertentu".

${ }^{24}$ In view of Nasr Hamid Abu Zaid, absoluteness Qur'an sacred limited in the form of metaphysical or while in lawh Mahfudz unknown substance and can not be proven, but merely the story of al-Quran. Then Qur'an is absolute and sacred becomes faded, relative and relative when revealed to the Prophet and understood by Muslims. This is because the absoluteness and the sanctity of the Quran has been lost while in the reading of the human intellect mixed with coloring and interests of each interpreter. Then the conclusion, according to Abu Zaid, the Qur'an is absolute and sacred is no longer in this world. Source: Henri Saladin, Qur'an Blasphemed (Jakarta: Al-Qalam, 2007).

${ }^{25}$ Hasan Hanafi dalam Ilham B. Saenong, 147-148.

${ }^{26}$ Hasan Hanafi, Humûm al-Fikr al-Waman: at-Turatswa al'Acrwa al-Hadâtsah Vol. II (Kairo: DârQubâ, 1997), 23-30.
}

Third, there is not false or true interpretation, right or wrong understanding. There is only the difference in the approach to the text which is determined by the difference in interest and motivation. Interpretation conflict express conflict of interest, the linguistic interpretation is always changing. Similarity between the meaning of the text that is being described and the meaning of the interpretation of the text are similar hypothesis. According to Hanafi, the time more than 14 centuries led to the theory of similar text and interpretation so impossible. Fourth, There is no single interpretation of the text, but a plurality of interpretations which are caused by differences understanding of interpreter, the text is merely a tool of interest, even human ambition. Interpreter gives content according to time and space in their future. Finally, conflicts of interpretation reflect the socio-political conflict and not theoretical conflict. The theory is really just a cover epistemological. Each interpretation reveals sociopolitical interpreter. Interpretation, according to Hanafi, is an ideological weapon used by many socio-political forces, both in order to maintain or change power. ${ }^{27}$

On the five above premise, Hanafi aims to avoid the rambling interpretation, therefore Hanafi formulate some characteristics in the interpretation of al-Qur'an. First, it should be capable to generate specific interpretation (attafsir al-juz'i ) that interpret certain verses of alQur'an instead of interpreting whole passages of the Qur'an. Second, this interpretation is also called thematic interpretation (at-tafsir almaudhu'i) because it only interprets certain themes required. Third, temporal, (at-tafsir azZamani). The interpretation is not directed to find general meaning, but rather it is directed to trace the appropriate meaning of Al-Qur'an to certain

\footnotetext{
${ }^{27}$ Hassan Hanafi, Islam In The Modern World: Religion, Ideology, and Development, vol. I (Kairo: Anglo-Egyptian Bookshop, 1995), 417-418.
} 
generation. These interpretations do not deal with the past or the future, but is associated with the contemporary reality in which it appears. Fourth, realistic character (at-tafsir al-waqi'i). Namely start interpretation from the reality of the Muslims, crises and tribulations faced by them. Fifth, oriented on particular significance and is not a theoretical discussion about letters and words. Because according to Hanafi, revelation basically has goal, orientations and interests. Namely the interests of the community and things that conceivably is humane, rational and natural. Sixth, is experimental, it is an interpretation appropriate with life and experiences of interpreter. Seventh, attention to contemporary problems. For Hanafi, mufassir can not start the interpretation without pay attention first and depth research on the problems of life. Finally, social position of mufassir determined pattern of interpretation he does. Interpretation is part of the social structure, whether it is part of top, middle or bottom. ${ }^{28}$

After laying the premises and characteristics of various interpretations, then Hanafi formulate some rules methodical to support hermeneutics of al-Qur'an he built. These rules serve as technical guidance when interpreting al-Qur'an. First: formulate political and social commitment. mufassir is not a neutral, because he stay on certain nation and crisis on it. He is obsessed on social change. There is no mufassir without specific commitments, because the loss of commitment means having no commitments. Secondly, looking for something. A mufassir does not begin the interpretation with bare hands or without knowing what he wants to know first. According to Hanafi, the awareness is interest in itself. While wisdom contained $a s b a b$ an-nuzul is a describing of reality priority on the text.

\footnotetext{
${ }^{28}$ Hasan Hanafi, ad-Dînwa at-Tsaurah fi Micr1952-1981, al-Yamînwa al-Yasâr fîfikri ad-Dînî Vol. 7 (Kairo: Maktabah Madbuli, 1989) 102-111.
}

Third, a mufassir try to make synopsis of verses related to certain themes. Each verse relates to one another in certain themes were collected, then is read and understood repeatedly carefully and simultaneously so that the general orientation of these verses can be found. Fourthly, the classification of linguistic forms. For Hanafi, language is a form of thinking that brings mufassir into meaning. Fifth, build structures. After linguistic forms giving meaning orientation, Mufassir try to build a structure from a meaning to an object. Meaning and object is the same side. Both are the same correlation in consciousness. Sixth, the analysis of factual situation. After laying a theme as an ideal structure, mufassir combine and connect with the real situation, to determine the status of quantitative problems. According to Hanafi, social diagnosis is another way to understand the meaning of a text in the real life. Seventh, compare the ideal with the real. after the process of building the structures, it provide a qualitative theme and analysis of social facts give quantitative status as a socio-historical phenomenon, Mufassir compare the ideal structure deduced from the text content analysis and factual situation and induced by statistics in the social sciences. Finally, a description of the action model, If it found the gap between the ideal and real world, the social action is the next step of interpretation process. Mufassir transform itself from text to action, from theory to practice and of understanding to change. ${ }^{29}$

According to Hassan Hanafi, the interpretation do not present in a vacuous, but rather manifest in time and a certain place in a certain historical as well. Therefore, people today are required to formulate a method of interpretation appropriate with interest, needs and problems faced by Muslims today ${ }^{30}$ Hassan Hanafi states that for a thorough revival in

\footnotetext{
${ }^{29}$ Hasan Hanafi dalam Ilham B. Saenong, 151-153.

${ }^{30}$ Hassan Hanafi, al-Din al-Din wa al-Tsaurah Fi Mishr 1952-1981 Vol.7, 1.
} 
religious reforms affecting social revolution and political Muslims, required interpretation methodologies which goes beyond the textual and historical interpretations, which are not positioned Al-quran in a narrow space and time on Prophet period, he calls it consciousness interpretation ( al-Tafsir al-Syu'uri ), that interpretation take alQur'an to describe humans, the relationship between the human, his duties in the world, its place in history, to build a social and political system. Hasan Hanafi used hermeneutics which developed and influenced by Western contemporary hermeneutics as a methodology for understand al-Qur'an. Nevertheless, according to him, hermeneutic is not only science of interpretation, but also the science explains the acceptance of a revelation from the level of words till practice in the world.

\section{Muskilat of al-Qur'an Hermeneutics}

In terminology, in the general meaning of hermeneutics is defined as the process of changing things or situations ignorance to know and understand (Palmer, Hermeneutics: Interpretation Theory in Schleiermacher, Dilthey, Heidegger and Gadamer). Hermeneutics generally divided into three terms. First, expressing feeling in words, translation and act as interpretation. Second, attempts to translate foreign language from unclear meaning into target language that can be understood by the reader. Third, expressing vague, feeling change become good expression.

In Islam, the al-Qur'an hermeneutics related to the understanding and interpretation has been known since the beginning of appearance of Islam. Problem understanding and interpretation initially focused on al-Qur'an, as it is part of the religion. On period of the Apostle of al-Qur'an thrive in an environment of dialogue and the process of interpretation. So that at the time of the Apostles and Companions (after the death of the Apostle considered authoritative cleft) growing discourse "oral interpretation" based on the history with the point of quality intellectual and spiritual. And after the era of bookkeeping in the 2 nd century, occurred transformation of oral to written culture as a pioneer on the development of "written interpretation" that makes the dilemma where on the one hand there was a strengthening of the existence of interpretation dirayah ( $\left.\mathrm{ra}^{\prime} \mathrm{yu}\right)$, but on the other hand forming establishment on riwayah interpretation.

The development of hermeneutic AlQur'an can be divided into two periods based on the methodology criterion, which is traditionally the period with the hermeneutic of al-Qur'an systematic pre-formulation, while the figures included in this era, al-Shafi'i in al Risalah indicated link between usul fiqh and hermeneutic of Qur'an through an emphasis on text understanding ( $\mathrm{al}$-Fahm ) and al-Jahidz emphasizes on creation of comprehension discourse (al-Ifham) that can be understood by argumentative audience, efficient and effective , As well as figures that combine an emphasis on text understanding ( $\mathrm{al}$-Fahm ) and an emphasis on the creation of comprehension discourse ( $a l$ Ifham ). He is Ibn Wahab in his book al-Burhan fi Wujuh al Bayan (but in the traditional period there are some characters that use al-Qur'an hermeneutics term to say the methodology and theory of interpretation used by research figures, like Auliffe which discusses the interpretation of al- Tabari and Ibn Kathir, Health who discusses the methodology of al-Tabari, Ibn Sina and Ibn 'Arabi. The contemporary period with alQur'an hermeneutics is systematic formulation. The figures included in this category, namely Sayyed Ahmad Khan, Ghulam Ahmad Parwez ( India), Muhammad Abduh (Egyptian), Hassan Hanafi, Fazlur Rahman, Arkoun, Farid Esack, Amina Wadud Muhsin etc.

According to Hassan Hanafi, the traditional interpretation based solely on the text, just move the sound of the text to reality, as if the religious texts that can speak for themselves. Yet in terms of epistemology traditional interpretation has drawbacks, they are: do not make reality as 
text, not a proof text be acceptable reality do not make reality as a reference, the text does not make unilateral, assume there is only one understanding of the text, the text does not directed to the ratio and the reality of the people and not fight Muslims as people but to fight Islam as well as the principle does not explain the calculation quantitatively. To finish it, Hanafi provide a solution, namely the interpretation of consciousness in order to take al-Qur'an to describe man, his relationship between the human, duties in the world, its place in history, to build a social and political system. Apply alternatives through experience analysis methods leads to the text and reality.

In genealogist, thematic interpretation formulated by Abdul Hayy al-Farmawi in his book Al-Bidayah fi Al-Tafsir Al-Mawdhu'. The thematic method used by Hassan Hanafi is a completion of the method Hayy al-Farmawi. According to the Hayy al-Farmawi, thematic interpretation is divided into two forms: the form of interpretation of a surah in Qur'an to explain the objectives generally and specifically. Hermeneutic of al-Qur'an is the developing of thematic interpretation bil-ma'tsur written by tahlili method that still leaves several weaknesses, such as: pieces of similar theme in several surah, the repetition of the same theme, there is no structural theme nationally and real, there is no a coherent ideology, interpretation has thick volume and make tired in reading, obscure information with knowledge, news inform separate the needs of soul and society now.

Hermeneutic al-Qur'an thematic has superior characteristics, including: deduce and induce a sense, makes Mufassir not only as recipient but the giver of meaning, not only analyze but synthesizing and interpreting to find something. According to Hassan Hanafi, hermeneutic al-Qur'an thematic has principles, as follows: Revelation is placed between accepted and rejected, al-Quran as a subject of interpretation, there is no right or wrong interpretation, in one text involved more than one interpretation and conflicts of interpretation it is socio-political conflict which is not a conflict in theory. According to Hassan Hanafi, the rule applied in hermeneutic al-Qur'an, is the socio-political commitment, looking for something, make an outline verses relating to certain basic themes, the classification is based on the linguistic, build structure, comparison between ideals and reality and elaboration of the model by performing an action. Restriction area hermeneutic al-Qur'an thematic based on three interconnected circles with one centre, namely: first, being, sein is individual awareness as the core of the world, the second, being with others shows the human world, the social world and subjectively, individual relationships with others. And third, being in the word, aussein, in-der-welt-sein shows the relationship of individual consciousness with the universe, the objects of the world.

The others thinking that strongly affect hermeneutic Hasan Hanafi in social pattern is called Marxism. Without Marxism, Hasan Hanafi also revolutionary who affected by Jamaluddin al-Afghani and Sayyid Qutb, but the experience acquainted with Marx and liberation theology makes patterned left and methodologically assist in analyzing the various contradictions in the reality of Muslims today. Hasan Hanafi borrowed instruments in Marxism, especially the dialectical method, in borrowing criticism in reality and testing text in reality. Hasan Hanafi has a suspicion toward hermeneutika objective which may be a certain class interests. Text and interpreters are also seen using a double structure as in the class structure of Marxism. This is what makes a hermeneutic not just theory, but also as continuum of historical criticism, interpretation until praxis, an elaboration of thought Marxism toward al-Qur'an that makes hermeneutic of alQur'an is liberation. Hermeneutics Hasan Hanafi is an intellectual struggle process of thought and social area.

To back up its commitment to reality, he describes a method called as manhaj al-ijtima $f i$ 
al-tafsir in his book "Dirasat Falsafah". On the basis of the basic principles as before he formulated the steps of interpretation that must be passed in interpretation.

1. The wishes of a Mufassir should be based on contemporary social conditions, he know and make commitments on the social problems.

2. To achieve a mufassir wish should reflect on reality of al-Quran are motivated by reality.

3. From the commitments and the objectives of the Mufassir investigate the verses relating to the theme of the commitment.

4. The verses are classified according to linguistic for the next step.

5. Build structures towards the intended target.

6. Identify problems and situations faced, either in the form of oppression, rights etc.

7. Correlate the ideal structure as a result of deduction text with the real problem induced from empirical reality through statistical calculations and social.

8. As the final step of the process of interpretation produces transformative practical formula to be realized. ${ }^{31}$

According to reality of the world today is characterized by double standards in ethics and value system, which is caused by capitalism and socialism division, liberalism and authoritarianism, east and west. The principle of duality or double standard is not only contrary to the theory, but also with struggle and action.

On the other hand the reality of the Islamic world today decorated by violence, civil war, torture and so on, illustrate away of Islam from a religion of peace and universal moral. Muslim society has not prepared to live in peace. During this time the Muslim community suffers, because social injustice, economic, and political. But if the injustice was removed, so the peace will be realized. According to purpose of gradual revelation is to prepare people, communities and

${ }^{31}$ Ibid., 106. nations to live in peace and security, if these objectives can be achieve between the real and the ideal is very close.

This commitment was confirmed Hanafi in the start interpreting "peace" which he further inventory verses pertaining to peace and classified, then connected with reality to look for in the ideal formula to peace.

Word of Salam, which means peace, with the entire derivation called repeatedly in the Qur'an, and the forms of nouns more than verbs. Noun is the substance, whereas the verb is action. So, peace is the objective reality is not just moods. The word of Salam with derivatives appear 157 times, 129 times noun (as noun 79 and adjective 50) and the verb 28 times. Peace is related to time, nature and the cosmos (al-Qadr, 97: 5) symbolically said peace is needed when in darkness and daylight.

Islam as a religion whose name is derived from the same root word as regards the means of peace, there are 50 times (noun of Islam word 8 times, 3 times a single adjective, plural adjective 39 times) because Islam is a religion of peace and peaceful behavior. When Islam used the name of belief, it becomes an action and lifestyle, individual, for both men and women. His desire was expressed in a greeting among Muslims "Assalamu'alaikum" when entering home also great by expressing Assalamu'alaikum, because the house is part of someone privacy. If someone is trespassing or breaking down, spying and so is a violation and contrary to widespread individual peace in family life and social life.

The statement of Islamization in the syahadah expression is Ashhadu, the verbs indicate a necessity of action, in this case is the negation, denial of all false gods, which includes the desire and lust. Moreover, the subsequent is incorporation of self-affirmation of the single principle and universal, which is shown by Muhammad. The same forms of verbal derivation is Salamah means accepting the decision without coercion (QS. an-Nisa', 4: 65). 


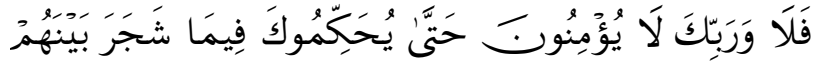

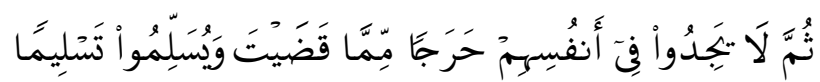

"But no, by your Lord, they will not (truly) believe until they make you (Muhammad), judge concerning that over which they dispute among themselves and then find within themselves no discomfort from what you have judged and submit in (full, willing) submission".

There is no peace without the compliance and implementation of the message, peace can not be imposed without the option, and if enforced would undermine the religion itself. ${ }^{32}$ Submission to God means liberation consciousness of human servitude to any load. Peace should be built jointly between the individual, society, state and nation by obedience to God and the realization of universal peace.

Peace is the arena of competition, which are equally subject themselves to God and his will to get internal peace is manifasted in righteousness, justice, fortitude, temperance, and the embodiment of a noble struggle very hard to deliver a loss of feeling discouraged, grief and arbitrariness. Peace is closely related to justice, injustice is the main cause of conflict and war, justice requires equality, partner alignment (QS. Jin, 72:14)

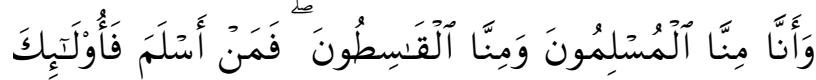

$$
\text { تَرَسَوْاٌ رَشَدًَا }
$$

"And among us are Muslims (in submission to Allah) and among us are unjust. And whoever has become Muslim-those have sought out the right course".

Covert war, poverty, abuse, discrimination, exploitation, violation of welfare distribution and

\footnotetext{
${ }^{32}$ Teks 01. 2002, 106.
}

so on as well as the physical war of invasion and aggression. During this time, the violence and the war will continue and peace to be restored. AlBaqarah: 233

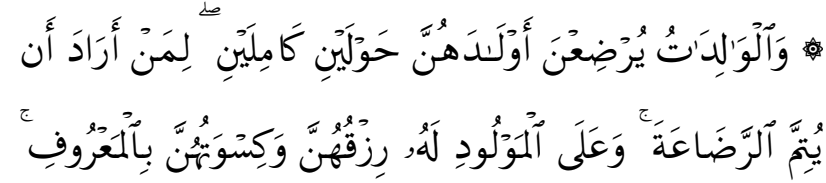

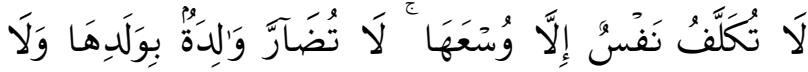

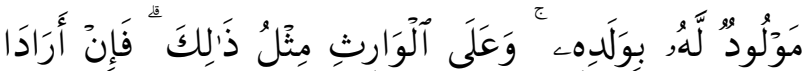

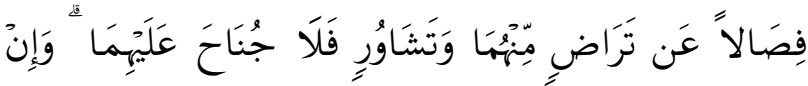

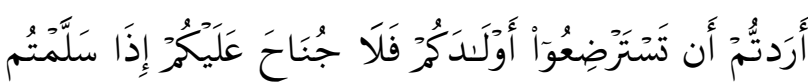

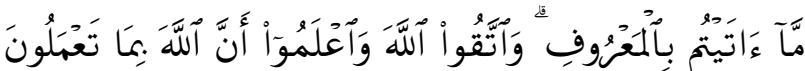
بَصِيرِ

"Mothers may breastfeed their children two complete years for whoever wishes to complete the nursing(period). Upon the father is the mothers' provision and their clothing according to what is acceptable. No person is charged with more than his capacity. No mother should be harmed through her child, and no father through his child. And upon the (father's) heir is (a duty) like that (of the father). And if they both desire weaning through mutual consent from both of them and consultation, there is no blame upon either of them. And if you wish to have your children nursed by a substitute, there is no blame upon you as long as you give payment according to what is acceptable. And fear Allah and know that Allah is seeing of what you do" (QS. alBaqarah, 2: 233).

\section{The Lack of Manhaj Tafsir al-Qur'an Hasan Hanafi}

If we look at the lack of Manhaj Tafsir alQur'an Hasan Hanafi interpretation that it is very susceptible to "rape" the text in order to support text and ideas, the ideas and ideals of the 
interpreter itself. It can be seen from Farid Esack case. Although he has set strict requirements and rules in the process of hermeneutics, but Esack still usually take incomplete argumentation, piece by piece, solely in order to justify his idea. This can be misleading in addition feared to occur "Hermeneutics prostitution", something that very criticized by himself. The same thing also happened to Gutierrez. The foundation that used is reality. According to him, the reality surrounding in communities are not ideal, not in accordance with what is mandated in scripture. Therefore, Gutierrez found the text or paragraph that can change and encourage people to a better state, in accordance with what he understood from the sacred text. It means, there is really subjective, there is no standardized parameters that can be used as a foundation of truth, except for the change of society itself. ${ }^{33}$

\section{Conclusions}

Hasan Hanafi hopes Tafsir as a theoretical interpretation of Quran formulated on various issues in society which must be applied in a practical level. He uses a thematic method that is characteristic of interpretation by the scientific paradigm, which expresses the subjectivity by emphasis on the interests of commitment and social commentators. Therefore, the characteristic of this Tafsir is temporal interests which ignore the past or the future. Hanafi used hermeneutics as an alternative method of interpretation of the text on a critique of the classical interpretation methods. Hanafi also expand the scope of hermeneutics, from the science of interpretation or theory of knowledge, up to a science that describes the acceptance of a revelation since the level of words to the world level. Hermeneutics is the study of the process of revelation of the letters to reality, from logos to practice, and also

\footnotetext{
${ }^{33}$ Achmad Khudori Soleh, "Membandingkan Hermeneutik dengan Ilmu Tafsir “, dalam Jurnal Tsaqafah, Vol. 7, No. $1,(2011), 48$
}

the transformation of the revelation of the mind of God to human life.

The thematic method used by Hassan Hanafi is a refinement method of Hayy alFarmawi. According to the Hayy al-Farmawi, thematic interpretation is divided into two forms: the form of interpretation of the letter of the Qur'an to explain the objectives generally and specifically. Hermeneutic Quran thematic is the development of thematic interpretation Bilma'tsur by Tahlili method that still have several weaknesses, such as: pieces of similar theme in several letters, the repetition of the same themes, the absence of structural theme which are rational and real, the absence of a coherent ideology, interpretation that the volume is very thick that so make tired in reading, obscure information with knowledge, the news that inform separately with the soul need and society recently.

Hanafi gave a new interpretation theory in interpreting the Quran which he formulated through a social approach, Hanafi called his interpretation theory was "social hermeneutics" (al-manhaj al-ijtima'i Fi at-Tafsir), or more precisely the method of thematic interpretation (at-Tafsir al-mauû'î). Hanafi also added by using this method, a mufassir who want to close to the meaning of the Quran not only deduce the meaning of the text, but also induce the meaning of reality into the text

\section{Bibliography}

Abu Ashi, M. Salim. Maqalatani fi at-Ta'wil Ma'alim fi al-Manhaj wa Rosd li alInhiraf. Kairo: Daar al-Bashair, 2003.

Adnin Armas. "Tafsir al-Qur'an atau "Hermeneutika Al-Qur'an" dalam Jurnal Pemikiran dan Peradaban Islam". Dalam Jurnal Islamia. Vol. I No. 1 (1425).

Agus Sachari. Budaya Visual Indonesia dan Permasalahannya. Jakarta: Erlangga, 2007. 
Ahmad Khudori Sholeh. Pemikiran Islam Kontemporer, Hasan Hanafi: Hermeneutika Humanistik. Yogyakarta: Jendela, 2003.

. "Membandingkan Hermeneutik dengan Ilmu Tafsir". dalam Jurnal Tsaqafah. Vol. 7, No. 1 (2011).

Al-aridl, A. H. Sejarah dan Metodologi Tafsir. Jakarta: Rajawali Pers, 1992.

Donohue, J. dan E.L. Islam dan Pembaharuan. Jakarta: Raja Grafindo Persada, 1995.

Ilham B. Saenong. Hermeneutika Pembebasan Metodologi Tafsir al-Qur'an Menurut Hasan Hanafi. Jakarta: Teraju, 2002.

Gharib, Fathi Muhammad. Raudhatul Bâhitsîn fî Manâhij al-Mufassirîn. Kairo: Al-Azhar University, 2007.

Hamersma, Herry. Tokoh-tokoh Filsafat Barat Modern. Jakarta: Gramedia, 1983.

Harun Hadiwijoyo. Sari Sejarah Filsafat Barat 2. cet. ke-24. Jogjakarta: Kanisius, 1980.

Hanafi, Hasan. At-Turâts wa at-Tajdîd: Mauqifunâ min al-Turâts al-Qadîm. Kairo: Al-Markaz Al-‘Arabî, 1980.

- Qadhâya Mu'âcirah Fî Fikrinâ al-Mu'acir Vol. 2. (Beirut: Dâr at-Tanwîr, 1983).

—. Dirasat Falsafiyyah. Kairo: Maktabah Anglo Mishriyyah, 1988.

_.ad-Dîn wa at-Tsaurah fi Micr1952-1981,
al-Yamîn wa al-Yasâr fî fikri ad-Dînî Vol.

7. Kairo: Maktabah Madbuli, 1989.

. Islam In The Modern World: Religion, Ideology, and Development. vol. I. Kairo: Anglo-Egyptian Bookshop, 1995.

- Humûm al-Fikr al-Waman: at-Turats wa al-'Acrwa al-Hadâtsah. Kairo: Dâr Qubâ, 1997.

- Hermeneutika al-Qur'an? Yogyakarta: Pesantren Nawesea Press, 2009.

Huijbers, Teo. Filsafat Hukum dalam Lintas Sejarah. Cet. ke-18. Jogjakarta: Pustaka Filsafat Kanisius, 1982.

'Iwad. Dirasat fi al-Hadlarat. Kairo: Dar alMustaqbal al-'Arabiy, 1989.

Jan Hendrik Rapar. Pengantar Filsafat. Yogyakarta: Kanisius, 1996.

Juhaya S. Praja. Aliran-aliran Filsaat dan Etika. Cet. ke-2. Jakarta: Kencana, 2005.

M. Mahmud. Islam Kiri. Jakarta: Gema Insani, 1999.

Muhammad Muslih. Filsafat Ilmu: Kajian atas Asumsi Dasar Paradigma dan Kerangka Teori Ilmu Pengetahuan. Cet. ke5. Yogyakarta: Belukar, 2008.

Henri Shalahuddin. Al-Qur'an Dihujat. Jakarta: Al-Qalam, 2007.

Simogaki, K. Kiri Islam. Yogyakarta, LKIS dan Pustaka Pelajar, 1994. 